\title{
Phenolic metabolism in the hornwort Anthoceros agrestis: 4-coumarate CoA ligase and 4-hydroxybenzoate CoA ligase
}

\author{
Julia Wohl ${ }^{1} \cdot$ Maike Petersen $^{1}$ (D) \\ Received: 13 February 2020 / Accepted: 2 May 2020 / Published online: 13 May 2020 \\ (c) The Author(s) 2020
}

\begin{abstract}
Key message 4-Coumarate coenzyme A ligase and 4-hydroxybenzoate coenzyme A ligase from the hornwort Anthoceros agrestis expressed in $E$. coli were characterized on biochemical and molecular levels and showed interesting substrate specificities.

Abstract Acyl-activating enzymes are associated with the biosynthesis or degradation of various metabolic products such as lipids, amino acids, sugars, and natural compounds. In this work, cDNA sequences encoding 4-coumarate coenzyme A ligase (4CL) and 4-hydroxybenzoate coenzyme A ligase (4HBCL) were amplified from the hornwort Anthoceros agrestis. The coding sequences were expressed in E. coli and purified by Ni-chelate chromatography. The CoA ligases exhibited different substrate specificities. 4CL catalyzed the activation of 4-coumaric acid, 3-coumaric acid, 2-coumaric acid, caffeic acid, isoferulic acid, ferulic acid, and cinnamic acid but lacked activities towards sinapic acid and benzoic acids. In contrast, 4HBCL preferred 4-hydroxybenzoic acid and benzoic acid, but also accepted other benzoic acid derivatives except salicylic acid and 3-aminosalicylic acid. Furthermore, 4HBCL also activated isoferulic acid, cinnamic acid, 2-coumaric acid, 3-coumaric acid, 4-coumaric acid and caffeic acid, but lacked affinity for ferulic acid and sinapic acid. These substrate specificities could be related to the phenolic compounds identified in Anthoceros agrestis.
\end{abstract}

Keywords Anthoceros agrestis · Benzoic acids $\cdot$ Coenzyme A ligase $\cdot$ Hornworts $\cdot$ Hydroxycinnamic acids · Phenylpropanoid metabolism

\section{Introduction}

The hornwort Anthoceros agrestis PATON (Anthocerotaceae) has recently been proposed as a model plant for investigations of developmental processes in hornworts and land colonization from the aquatic environment by plants (Szövényi et al. 2015) most probably from a member of the Zygnematophyceae (Wickett et al. 2014; Rensing 2018). The conquest of land posed a number of challenges to plants, amongst

Communicated by Günther Hahne.

Electronic supplementary material The online version of this article (https://doi.org/10.1007/s00299-020-02552-w) contains supplementary material, which is available to authorized users.

Maike Petersen

petersen@staff.uni-marburg.de

1 Institut für Pharmazeutische Biologie Und Biotechnologie, Philipps-Universität Marburg, Robert-Koch-Str. 4, 35037 Marburg, Germany others the necessity to develop cell wall reinforcements and strategies against water loss as well as UV screens and defences against herbivores and pathogens. Various phenolic compounds deduced from the aromatic amino acids L-phenylalanine and - to a lesser extent—L-tyrosine are known to contribute to overcoming these challenges. In hornworts, phenolic metabolism is especially elaborated. More than 25 phenylpropanoid-derived specialized compounds have been described in phytochemical investigations of Anthoceros agrestis (Takeda et al. 1990; Trennheuser 1992; Trennheuser et al. 1994; Vogelsang et al. 2006). The most prominent phenolic compound is rosmarinic acid (RA), an ester of caffeic acid and 3-(3,4-dihydroxyphenyl)lactic acid which is especially well known as compound occurring in species of the Lamiaceae and Boraginaceae, but turning up as specialized metabolite sporadically throughout the plant kingdom (Petersen and Simmonds 2003; Petersen et al. 2009). The biosynthesis of RA has been fully elucidated in Coleus blumei (Lamiaceae) on molecular and biochemical levels (Petersen et al. 1993). One of our current interests is 
to show whether the ability to synthesize RA has evolved once or several times independently during evolution. For this purpose, the enzymes and genes of the phenylpropanoid pathway and RA biosynthesis in Anthoceros agrestis are under investigation.

Acyl-activating enzymes (AAEs) are responsible for the activation of carboxylic acids through a two-stage reaction (Shockey and Fulda 2003). In the first step, the substrate is activated by transfer of AMP from ATP under release of pyrophosphate. The resulting unstable substrate-AMP intermediate remains bound in the active center of the enzyme. In the second step, free electrons of the sulfur group of the acyl acceptor coenzyme A causes a nucleophilic attack on the carbon atom of the carboxyl group, thereby AMP is released and a thioester is formed. There are several AAEs that allow the activation of various substrates like acetate and fatty acids of different length (Watkins 1997), benzoic acid derivatives (Chang et al. 1997), cinnamic acid derivatives (Ehlting et al. 1999) or citrate, malate and malonate (An et al. 1999). In most cases, the acyl moiety is transferred to coenzyme A, but other acceptors are also described, for example, amino acids or molecular oxygen (Conti et al. 1996; Staswick and Tiryaki 2004).

The formation of 4-coumaroyl-CoA (4-hydroxycinnamoyl-CoA) is the last step in the core phenylpropanoid pathway and 4-coumaroyl-CoA is the precursor for many specialized metabolites. The reaction is catalyzed by 4-coumarate coenzyme A ligase (4CL; E.C. 6.2.1.12). In addition to 4-coumaric acid cinnamic, caffeic, ferulic, isoferulic and sinapic acids are often accepted. Nevertheless, phenylpropanoid CoA ligases differ substantially in substrate specificity and preference (Lindermayr et al. 2002). Schneider et al. (2003) identified 12 amino acids proposed to function as the 4CL substrate specificity code, two of these 12 amino acids were essential for acceptance of sinapic acid. In plants, the 4CL protein is found soluble in the cytosol. Usually several paralogs are found in plants and they mostly have different expression patterns (Renault et al. 2019). A phylogenetic analysis of almost $2004 \mathrm{CL}$ sequences suggested that a duplication event had taken place in seed plants before the split of gymnosperms and angiosperms (Li et al. 2015). Homologs of 4CL are already present in the genomes of green algae, red algae, glaucophytes, diatoms, dinoflagellates, haptophytes, cryptophytes, and oomycetes (Labeeuw et al. 2015). Therefore, it is proposed that the gene set enabling the formation of phenylpropanoids had been evolved prior to the appearance of lignin as cell-wall reinforcing structure.

Benzoic acid derivatives can either be synthesized directly from intermediates of the shikimate pathway, mainly leading to salicylic acid and its derivatives, or from the phenylpropanoid pathway by $\beta$-oxidative chain shortening of cinnamic acid or 4-coumaric acid leading to benzoic acid (BA) or 4-hydroxybenzoic acid (4HBA), respectively. On the other hand, benzoic acids can also be produced by a non-oxidative pathway in the cytosol (Wildermuth 2006; Widhalm and Dudareva 2015). Probably the most prominent representative of the BAderived products is salicylic acid (SA) and its volatile form methyl-SA (Leon et al. 1995; Ogawa et al. 2005; Ogawa et al. 2006; Pan et al. 2006; Sawada et al. 2006). SA is nowadays regarded as a plant hormone and signaling compound not only involved in local and systemic disease defense responses but also involved in other processes, e.g., thermoregulation (Vlot et al. 2009). Benzoic acid functions as a precursor for aromatic cytokinins (Werbrouck et al. 1996; Strnad 1997; Tarkowská et al. 2003; Mutui et al. 2012), aroma and flavor compounds (Wang and De Luca 2005; Goff and Klee 2006; Dudareva et al. 2006, 2013; Schwab et al. 2008) and plant defense metabolites (Dudareva et al. 2004; Qualley and Dudareva 2008; Köllner et al. 2010). 4-Hydroxybenzoic acid is supposed to be involved in the biosynthesis of ubiquinone (Gaisser and Heide 1996; Block et al. 2014; Tohge et al. 2014), although the exact pathway is yet unclear.

Benzoate coenzyme A ligases have rarely been described in plants. Bacterial benzoate CoA ligases (badA) function in the anaerobic degradation of diverse aromatic compounds (Gibson et al. 1994; Egland et al. 1995). In Arabidopsis thaliana, a benzoate CoA ligase (E.C. 6.2.1.25) is involved in the formation of benzoyloxyglucosinolates (Kliebenstein et al. 2007) and an $o$-succinylbenzoate CoA ligase (E.C. 6.2.1.26) in phylloquinone biosynthesis (Kim et al. 2008). Furthermore, benzoate CoA ligase is putatively involved in the biosynthesis of the floral scent compound benzylbenzoate in Clarkia breweri (Beuerle and Pichersky 2002). 3- and 4-Hydroxybenzoate CoA ligases (E.C. 6.2.1.37, 6.2.1.27) act in xanthone biosynthesis in Centaurium erythraea (Barillas and Beerhues 1997) and benzophenone biosynthesis in Hypericum androsaemum (Schmidt and Beerhues 1997). A cinnamoyl CoA ligase also forming benzoyl-CoA has been characterized from Petunia hybrida (Klempien et al. 2012).

In this work, we describe the functional expression of two coenzyme A ligases from the hornwort Anthoceros agrestis, both with specific substrate affinities. The first, a 4CL, only accepted hydroxycinnamic acids, preferably coumaric and isoferulic acid but not benzoic acid derivatives. The other CoA ligase preferably accepted benzoic acid or monohydroxylated benzoic acids (except salicylic acid) and a range of other benzoic acid derivatives as well as some (hydroxy) cinnamic acids. To our knowledge, this is the first report on a (4-hydroxy)benzoate coenzyme A ligase (4HBCL) in bryophytes and the first functional characterization of $4 \mathrm{CL}$ from hornworts. 


\section{Materials and methods}

\section{Plant cell cultures}

Anthoceros agrestis cell suspension cultures were cultivated as described previously (Petersen 2003).

\section{Preparation of CDNA and amplification of partial sequences of $A a 4 C L$ and $A a 4 H B C L$}

RNA isolation was performed according to Chomczynski and Sacchi (1987). cDNA was prepared with the RevertAid $^{\text {TM }}$ First Strand cDNA Synthesis Kit (Fermentas) after checking RNA integrity. Internal PCR primers were designed based on Anthoceros agrestis scaffold 35,279 (Szövenyi, personal communication; Szövényi et al. 2015) and Anthoceros punctatus (a close relative to A. agrestis) scaffold 6378 (Anthoceros punctatus database: https://bioin formatics.plants.ox.ac.uk/anthoceros/blast.html). All primers were synthesized by Eurofins Genomics (for primer sequences see Suppl. Table S1). PCR assays of $25 \mu \mathrm{l}$ were conducted with up to $0.2 \mu \mathrm{g}$ cDNA, $0.5 \mu 110 \mathrm{mM}$ dNTP mix, $0.5 \mu 1$ of each primer (Aa35279_f + Aa35279_r; AaAp6378_f+AaAp6378_r $100 \mu \mathrm{M}), 3.0 \mu \mathrm{l} 25 \mathrm{mM} \mathrm{MgCl}_{2}$, $5.0 \mu \mathrm{l} 5 \times$ GoTaq buffer and $0.1 \mu \mathrm{l} \mathrm{GoTaq}$ polymerase $(5 \mathrm{U} / \mu \mathrm{l}$, Promega) using the following program: 1 cycle $94{ }^{\circ} \mathrm{C} 120 \mathrm{~s}$, $52-60{ }^{\circ} \mathrm{C} 60 \mathrm{~s}, 70{ }^{\circ} \mathrm{C} 90 \mathrm{~s} ; 38$ cycles $94{ }^{\circ} \mathrm{C} 30 \mathrm{~s}, 52-60{ }^{\circ} \mathrm{C}$ $60 \mathrm{~s}, 70{ }^{\circ} \mathrm{C} 90 \mathrm{~s} ; 1$ cycle $94{ }^{\circ} \mathrm{C} 120 \mathrm{~s}, 52-60{ }^{\circ} \mathrm{C} 60 \mathrm{~s}, 70{ }^{\circ} \mathrm{C}$ $600 \mathrm{~s}$. Isolation of PCR products was done with the NucleoSpin Gel and PCR Clean-up Kit (Macherey-Nagel) after agarose gel electrophoresis. The sequence was determined (Seqlab) after ligation into pDrive (Qiagen), transformation and multiplication in E. coli EZ (Qiagen).

\section{RACE-PCR and amplification of full-length Aa4CL and $\mathrm{Aa} 4 \mathrm{HBCL}$ sequences}

According to the sequences determined in the previous step, RACE primers (Aa35279_5'R, Aa35279_3'R, AaAp6378_5'R, AaAp6378_3'R; Suppl. Table S1) were designed. RACE-PCR cDNA synthesis and PCR were performed using the SMARTer ${ }^{\circledR}$ RACE $5^{\prime} / 3^{\prime}$ kit (Takara/ Clontech). After the isolation of the PCR products (NucleoSpin Gel and PCR Clean-up Kit, Macherey-Nagel) and ligation into pDrive, E. coli $\mathrm{EZ}$ were transformed and grown overnight. The plasmid was isolated and the sequence determined (Seqlab). Two potential start codons were found for Aa4CL. For the amplification of the full-length sequences of Aa4CL and Aa4HBCL, primers with restriction sites were designed for XhoI (Aa35279) and PstI (AaAp6378) in the forward and HindIII in the reverse primer (Aa35279_fl_f,
Aa35279_f1_r, AaAp6378_f11_f, AaAp6378_f12_f, AaAp6378_fl_r; Suppl. Table S1) for integration into the expression vector pRSET C (Invitrogen). PCRs of $25 \mu \mathrm{l}$ were performed as above but with Phusion ${ }^{\circledR}$ High-Fidelity DNA Polymerase (2 U/ $\mu \mathrm{l}$; NEB) and buffer (NEB) using the same PCR program as above, but with annealing temperatures of $58^{\circ} \mathrm{C}$ for Aa35279 and $59^{\circ} \mathrm{C}$ for AaAp6378. E. coli EZ cells were transformed after the ligation of the purified PCR products into pDrive. The Aa4HBCL (= Aa35279) full-length sequence (GenBank MN922306) and the two full-length sequences of Aa4CL (= AaAp6378) with alternative start codons (Aa4CL_1 and Aa4CL_2; GenBank MN922305) were integrated into the expression vector pRSET C. By integration, the sequences were attached to the sequence encoding an $N$-terminal 6xHis-tag already present on the expression vector pRSET $\mathrm{C}$. The sequences were again checked for correctness (Seqlab) after transformation ( $E$. coli $\mathrm{EZ}$ ) and plasmid isolation.

\section{Protein expression, isolation, and purification}

E. coli SoluBL21 (Amsbio) were transformed with the plasmids containing Aa4HBCL, Aa4CL_1 or Aa4CL_2. Plasmid uptake and correctness of the sequence were once again checked after plasmid isolation. SoluBL21 transformants were incubated in LB or TB media (Lessard 2013) containing $100 \mu \mathrm{g} / \mathrm{ml}$ ampicillin for $2-3 \mathrm{~h}$ at $37^{\circ} \mathrm{C} 160 \mathrm{rpm}$ up to an $\mathrm{OD}_{600}$ of 0.4-0.6. Then protein formation was induced with $1 \mathrm{mM}$ isopropyl- $\beta$-D-galactopyranoside (IPTG) and the cultures were incubated overnight at $25^{\circ} \mathrm{C}$ and $160 \mathrm{rpm}$. Cells were harvested by centrifugation $\left(3000 \mathrm{~g}, 4{ }^{\circ} \mathrm{C}, 5 \mathrm{~min}\right)$ and the pellet was resuspended in $4 \mathrm{ml}$ buffer $\left(0.1 \mathrm{M} \mathrm{K}_{2} \mathrm{HPO}_{4} /\right.$ $\mathrm{KH}_{2} \mathrm{PO}_{4} \mathrm{pH}$ 8.0). The cells were disrupted by ultrasonication on ice $(5 \times 30 \mathrm{~s}, 100 \%, 0.3$ cycles $)$ after $30 \mathrm{~min}$ incubation with appr. $50 \mathrm{mg}$ lysozyme. The crude protein extract was obtained by centrifugation $\left(5000 \mathrm{~g}, 4^{\circ} \mathrm{C}, 20 \mathrm{~min}\right)$ and was further purified on Ni-NTA resin (Novagen) via the $\mathrm{N}$-terminally attached 6xHis-tag to obtain highly enriched Aa4CL or Aa4HBCL protein. After adjusting the crude protein extract to $10 \mathrm{mM}$ imidazole and $300 \mathrm{mM} \mathrm{NaCl}$, $1 \mathrm{ml}$ pre-equilibrated Ni-NTA resin was added and incubated on ice for $1 \mathrm{~h}$. The resin was washed with $6 \mathrm{ml}$ wash buffer $\left(50 \mathrm{mM} \mathrm{K} \mathrm{HPO}_{4} / \mathrm{KH}_{2} \mathrm{PO}_{4} \mathrm{pH} 8.0,15 \mathrm{mM}\right.$ imidazole, $300 \mathrm{mM} \mathrm{NaCl})$ and eluted with $3 \mathrm{ml}$ elution buffer $(50 \mathrm{mM}$ $\mathrm{K}_{2} \mathrm{HPO}_{4} / \mathrm{KH}_{2} \mathrm{PO}_{4} \mathrm{pH} 8.0,250 \mathrm{mM}$ imidazole, $300 \mathrm{mM}$ $\mathrm{NaCl}$ ). The elution fractions were desalted by gel filtration through PD-10 columns (GE Healthcare) into $0.1 \mathrm{M}$ $\mathrm{K}_{2} \mathrm{HPO}_{4} / \mathrm{KH}_{2} \mathrm{PO}_{4}$ buffer $\mathrm{pH}$ 7.0. All protein concentrations were determined according to Bradford (1976) using bovine serum albumin $(1 \mathrm{mg} / \mathrm{ml})$ as a standard after verification of linearity between absorption and protein concentration with a calibration curve. The purified protein preparations were stored at $-80^{\circ} \mathrm{C}$. 


\section{SDS-PAGE and Western blotting}

Protein extracts were subjected to SDS-PAGE essentially according to Laemmli (1970). After SDS-PAGE, the gel was either stained with Coomassie Brilliant Blue R250 or Western blotting was performed basically as specified by Mahmood and Yang (2012), but applying the Towbin et al. (1979) buffer system. The expressed proteins were detected with mouse anti-6xHis-tag monoclonal antibodies (ThermoFisher, MA1-21315), followed by goat anti-mouse antibodies conjugated to alkaline phosphatase (Life Technologies, A16087) as secondary antibody. Staining was performed with nitro blue tetrazolium chloride (NBT)/5bromo-4-chloro-3-indolyl-phosphate (BCIP) following the standard protocol on https://www.sysy.com/protocols/blot. php. In short, the alkaline phosphatase coupled to the secondary antibody dephosphorylates BCIP and the resulting indoxyl dimerizes after oxidation by NBT resulting in a dark blue color (Sambrook and Russell 2001).

\section{Standard assays for coenzyme $A$ activation of (hydroxy)cinnamic acid derivatives}

Formation of CoA-esters from (hydroxy)cinnamic acid derivatives was determined photometrically at the absorption maxima published by Stöckigt and Zenk (1975) and Zenk (1979). A standard assay consisted of $100 \mathrm{mM}$ $\mathrm{K}_{2} \mathrm{HPO}_{4} / \mathrm{KH}_{2} \mathrm{PO}_{4} \mathrm{pH} 7.0,2 \mu \mathrm{g}$ (Aa4CL) or $32 \mu \mathrm{g}(\mathrm{Aa} 4 \mathrm{H}-$ BCL) purified protein, $1 \mathrm{mM}$ dithiothreitol (DTT), $2.5 \mathrm{mM}$ ATP, $2.5 \mathrm{mM} \mathrm{MgCl}{ }_{2}$ and $500 \mu \mathrm{M}$ (hydroxy)cinnamic acid. While testing caffeic acid as substrate, DTT was omitted, because the spectrophotometric assay was disturbed by DTT. The assay was incubated at $40{ }^{\circ} \mathrm{C}$ for $1 \mathrm{~min}$ and then the reaction was started by addition of $500 \mu \mathrm{M} \mathrm{CoA}$ and incubated for $8 \mathrm{~min}$; absorption was recorded throughout the incubation time. The specific activity was calculated using the measured slope of the absorbance and the respective extinction coefficient published by Stöckigt and Zenk (1975) and Zenk (1979) for the (hydroxy)cinnamoyl-CoA thioesters. Data for kinetic analyses for Aa4CL were obtained from three independent protein isolations with at least three technical replicates for each substrate concentration. The results were analyzed with the GraphPad Prism 5 software using Michaelis-Menten, Lineweaver-Burk (not shown) and Hanes-Woolf models.

\section{Standard assays for coenzyme $A$ activation of (hydroxy)benzoic acid derivatives}

\section{Direct assay}

The activation of 4-hydroxybenzoic acid was measured photometrically at $300 \mathrm{~nm}$. A standard assay for Aa4HBCL consisted of $100 \mathrm{mM} \mathrm{K} \mathrm{HPO}_{4} / \mathrm{KH}_{2} \mathrm{PO}_{4} \mathrm{pH} 7.0,15 \mu \mathrm{g}$ purified protein, $1 \mathrm{mM}$ DTT, $2.5 \mathrm{mM}$ ATP, $2.5 \mathrm{mM} \mathrm{MgCl}_{2}$, and $500 \mu \mathrm{M}$ 4-hydroxybenzoic acid. The assay was incubated at $45{ }^{\circ} \mathrm{C}$ for $1 \mathrm{~min}$ and then the reaction was started by the addition of $500 \mu \mathrm{M} \mathrm{CoA}$ and incubated for $8 \mathrm{~min}$; absorption was recorded throughout the incubation time. The specific activity was calculated with the extinction coefficient for 4-hydroxybenzoyl-CoA of $13 \mathrm{~cm}^{2} / \mu \mathrm{mol}$ (Biegert et al. 1993). Data for kinetic values were measured using purified enzyme from three independent protein isolations with three technical replicates for each substrate concentration. The results were analyzed with the GraphPad Prism 5 software using Michaelis-Menten, Lineweaver-Burk (not shown) and Hanes-Woolf models.

\section{Indirect assay}

For the determination of CoA ligase activities with all other (hydroxy)benzoic acid derivatives, we established an indirect spectrophotometric assay using hexokinase (Sigma) and glucose-6-phosphate dehydrogenase (G6PDH, Fluka) to determine the remaining ATP concentration after incubation by measuring the conversion of NADP to NADPH at $340 \mathrm{~nm}$ in a two-step assay. The CoA ligase assay consisted of $250 \mu \mathrm{l}$ $100 \mathrm{mM}$ Tris-HCl, $\mathrm{pH}$ 7.5, $14 \mu \mathrm{g}$ purified enzyme, $1 \mathrm{mM}$ DTT, $500 \mu \mathrm{M}$ ATP, $500 \mu \mathrm{M} \mathrm{MgCl}_{2}, 500 \mu \mathrm{M}$ (hydroxy)benzoic acid derivative, and $500 \mu \mathrm{M} \mathrm{CoA}$. After incubation for $1 \mathrm{~h}$ at $40^{\circ} \mathrm{C}$, the reaction was stopped by heating for $5 \mathrm{~min}$ at $95{ }^{\circ} \mathrm{C}$ and cooling on ice. $750 \mu \mathrm{l}$ reaction mixture consisting of $100 \mathrm{mM}$ Tris-HCl, pH 7.5, $200 \mu \mathrm{M}$ NADP, $200 \mu \mathrm{M}$ glucose, $1 \mathrm{U}$ hexokinase, and $1 \mathrm{U}$ G6PDH was added and the absorption at $340 \mathrm{~nm}$ recorded for $20 \mathrm{~min}$ at $25^{\circ} \mathrm{C}$. In principle, the addition of glucose and hexokinase results in the ATP-dependent formation of glucose-6-phosphate which is oxidized to 6-phosphogluconolactone by G6PDH under reduction of NADP to NADPH which is measured at $340 \mathrm{~nm}$. Kinetic values could not be determined with this method, as a difference in the ATP concentration added in saturating concentrations was not measurable after 3-min reaction time which was used to ensure the determination of initial reaction velocities.

\section{LC-MS analysis}

Conversion of (hydroxy)benzoic acids was additionally analyzed by LC-MS. Assays were performed using $100 \mu \mathrm{l}$ reaction volume consisting of $100 \mathrm{mM} \mathrm{K} \mathrm{HPO}_{4} / \mathrm{KH}_{2} \mathrm{PO}_{4}, \mathrm{pH}$ 7.0, 7.5 $\mu \mathrm{g}$ (Aa4CL) or $28 \mu \mathrm{g}$ (Aa4HBCL) purified enzyme, $1.25 \mathrm{mM}$ ATP, $1.25 \mathrm{mM} \mathrm{MgCl}_{2}, 500 \mu \mathrm{M}$ (hydroxy)benzoic acid derivative and $1 \mathrm{mM} \mathrm{CoA}$. Assays were incubated at $40{ }^{\circ} \mathrm{C}$ for $30 \mathrm{~min}$ (Aa4HBCL, Aa4CL with 2-coumaric and 3 -coumaric acid) or $60 \mathrm{~min}$ at $35^{\circ} \mathrm{C}$ (Aa4CL with hydroxybenzoic acids). An assay with heat-denatured protein 
$\left(10\right.$ min at $\left.95{ }^{\circ} \mathrm{C}\right)$ served as negative control. Assays were stopped on ice by the addition of $100 \mu \mathrm{l}$ methanol. After centrifugation for $10 \mathrm{~min}$ at $15,000 \mathrm{~g}, 15 \mu \mathrm{l}$ of the supernatant was analyzed by LC-MS. LC was performed on a HPLC 1260 (Agilent Technologies) with a Multospher 120 RP18 column $(250 \times 2 \mathrm{~mm}$; particle size $5 \mu \mathrm{m})$ using a solvent system of $\mathrm{A}=0.1 \%(\mathrm{v} / \mathrm{v})$ aqueous formic acid, $\mathrm{B}=$ acetonitrile with $0.1 \%(\mathrm{v} / \mathrm{v})$ formic acid at a flow rate of $0.5 \mathrm{ml} /$ min and a temperature of $25^{\circ} \mathrm{C}$ with the following gradient: $0-10$ min $5 \% \mathrm{~B} \rightarrow 100 \% \mathrm{~B} ; 10-15 \min 100 \% \mathrm{~B} ; 15-15.1 \mathrm{~min}$ $100 \% \mathrm{~B} \rightarrow 5 \% \mathrm{~B} ; 15.1-20 \mathrm{~min} 5 \%$ B. Detection was performed with the mass spectrometer micrOTOF-Q III with ESI source (Bruker Daltonics) calibrated with $5 \mathrm{mM}$ sodium formate using the negative mode.

\section{Results}

\section{Isolation of CDNAs encoding $4 \mathrm{CL}$ and $4 \mathrm{HBCL}$ from Anthoceros agrestis}

A nucleotide sequence of a putative 4CL (Anthoceros punctatus scaffold 6378; Kelly, personal communcation) has been identified by nucleotide BLAST search using a 4CL sequence from Melissa officinalis (FN665699.1) in the Anthoceros punctatus database (https://bioinformatics. plants.ox.ac.uk/anthoceros/blast.html). A partial sequence with primers directed against the $A$. punctatus sequence was amplified using cDNA from A. agrestis. After RACE-PCR, we obtained two potential Aa4CL full-length sequences due to two possible start codons. The open reading frames of the two sequences consisted of 1647 bp (Aa4CL_1) and 1599 bp (Aa4CL_2), encoding proteins of 548 amino acid residues $(58.42 \mathrm{kDa})$ and 532 amino acid residues $(56.86 \mathrm{kDa})$, respectively. The Aa4CL nucleotide sequence was deposited in GenBank under the accession number MN922305. The longer as well as the shorter amino acid sequence showed the highest identity (BLASTp) with 64\% to a 4CL from the gymnosperm Cryptomeria japonica var. sinensis (QDC33553.1) which, however, has not been characterized biochemically.

On the search for further 4CL candidates, Anthoceros agrestis scaffolds 19917, 20832 and 35279 (Szövenyi, personal communication; Szövényi et al. 2015) were identified. Aa19917 seemed to be not expressed since amplification of a partial sequence with different primer combinations worked only using genomic DNA but not with cDNA (data not shown). The encoded protein of Aa20832 was synthesized in E. coli, but demonstrated no activity towards different cinnamic or benzoic acid derivatives and was thus not further characterized (data not shown).

The encoded protein of Aa35279 was later revealed to be active as a (4-hydroxy)benzoate CoA ligase (4HBCL;
GenBank MN922306). After PCR amplification with primers directed against a partial sequence of $798 \mathrm{bp}$, RACE-PCR was performed to obtain the 5'- and 3 '-ends of the cDNA. The full open reading frame of Aa4HBCL consisted of $1704 \mathrm{bp}$ and could be translated into a protein of 567 amino acid residues with a molecular mass of $61.84 \mathrm{kDa}$. With an identity of $60 \%$, the amino acid sequence was closest to 4-coumarate CoA ligase-like 1 from Selaginella moellendorfii (XP_002981856.1) in a BLASTp search.

Alignment of the two newly identified CoA ligase amino acid sequences from Anthoceros agrestis (EMBOSS Needle) resulted in an identity of $39.3 \%$ and a similarity of $58.5 \%$ to each other. Furthermore, the two CoA ligases from Anthoceros agrestis were aligned with different plant 4CLs and the two already characterized CoA ligases with benzoateactivating properties from Arabidopsis thaliana (Q9SS01) and Clarkia breweri (AEO52695.1) (Fig. 1). The alignment shows that the two motifs box I ([STG][STAG]G[ST][STEI] [SG]X[PASLIVM][KR]) and box II (GEICIRG), corresponding to the core motifs $\mathrm{A} 3$ and A6 from the phenylalanine-activating subunit (PheA) of gramicidin synthetase 1 (Conti et al. 1997; Stuible and Kombrink 2001), are highly conserved throughout the 4CL sequences and Aa4HBCL. In the two benzoate-activating enzymes, at least two amino acids in the core of both boxes differed. Schneider et al. (2003) identified 12 amino acids proposed to function as the $4 \mathrm{CL}$ substrate specificity code. These amino acids were all conserved in the characterized 4CLs and Aa4CL (Fig. 1, marked in green). In the benzoate-activating enzymes and Aa4HBCL, however, some of these amino acids differed (marked in yellow in Fig. 1). Three changes were particularly noticeable: N288T, G380A and V390I or V390A.

\section{Expression of $\mathrm{Aa} 4 \mathrm{CL}$ in $E$. coli and characterization of $\mathrm{Aa} 4 \mathrm{CL}$}

Aa4CL protein with an $N$-terminally attached $6 x H i s$ tag was synthesized in E. coli SoluBL21. After a first proof of enzyme activity using crude protein extract, the protein was purified by metal chelate chromatography to afford nearly pure protein that was identified by SDS-PAGE followed by Western blotting (Suppl. Fig. S1). Catalytic activity of the expressed protein could be detected for the substrates caffeic, 2-coumaric, 3-coumaric, 4-coumaric, cinnamic, ferulic and isoferulic acid. While there was a clear increase in the absorption for Aa4CL, no absorption change was noticed in the empty vector control. Sinapic acid as well as different benzoic acid derivatives (benzoic, salicylic, 4-hydroxybenzoic, 2,3-dihydroxybenzoic, 2,4-dihydroxybenzoic and protocatechuic acid) were not accepted (Suppl. Figs. S2, S3 and S4). The latter were assessed by LC-MS analyses and caffeic acid was used as a positive control. For the produced CoA esters analyzed by LC-MS, we observed the $[\mathrm{M}-\mathrm{H}]$ pseudo 


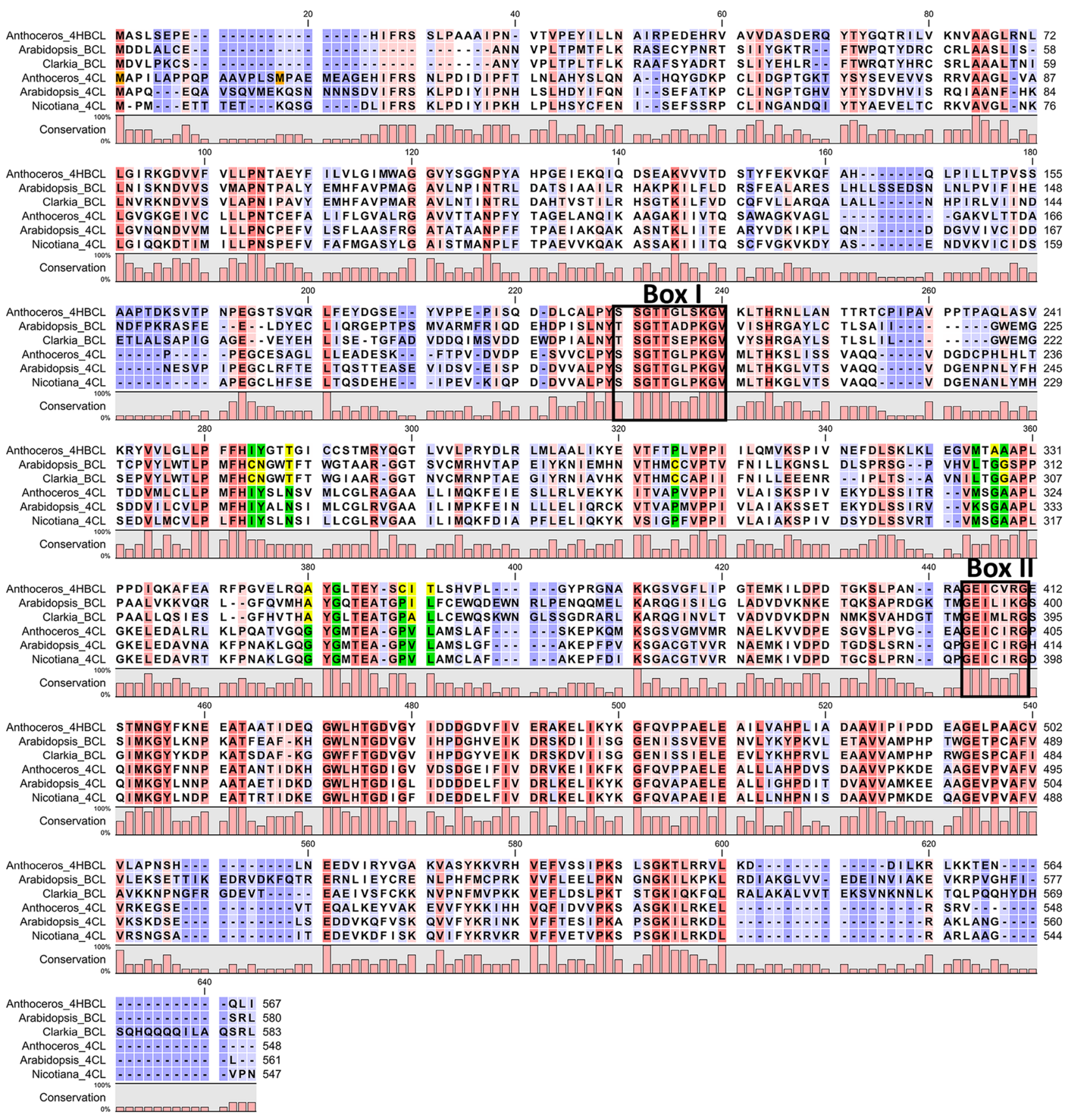

Fig. 1 Alignment of amino acid sequences of different CoA ligases (4HBCL $=4$-hydroxybenzoate $\mathrm{CoA}$ ligase, $\mathrm{BCL}=$ benzoate $\mathrm{CoA}$ ligase, $4 \mathrm{CL}=4$-coumarate $\mathrm{CoA}$ ligase) from Anthoceros agrestis (4CL: MN922305 and 4HBCL: MN922306), Arabidopsis thaliana (Q9SS01), Clarkia breweri (AEO52695.1), Arabidopsis thaliana (Q42524) and Nicotiana tabacum (O24145). Highly conserved amino

molecular ion as well as the doubly charged molecular ion [M/2]-H, as already reported by Beuerle and Pichersky (2002) for benzoyl-CoA. acids are marked red, low conservation is marked blue. Typical conserved sequence motifs are marked by boxes. Amino acids from the 4CL substrate specificity code (Schneider et al. 2003) are highlighted green, and amino acids differing from this code are highlighted yellow. The two possible start methionine residues of Aa4CL are highlighted orange (color figure online)

To ascertain the $\mathrm{pH}$ as well as the temperature optima of the enzymes, additional assays using ferulic acid were performed showing a $\mathrm{pH}$ optimum between $\mathrm{pH} 7.0$ and 7.5 
in a $100 \mathrm{mM}$ potassium phosphate buffer and a temperature optimum at $40{ }^{\circ} \mathrm{C}$ (Suppl. Fig. S5).

Kinetic data for Aa4CL_1 and Aa4CL_2 were determined for 4-coumaric acid, caffeic acid, ferulic acid, isoferulic acid, and cinnamic acid as hydroxycinnamic acid substrates. Although Aa4CL_2 demonstrated higher specific activities (around twice) compared to the longer variant Aa4CL_1, the substrate affinities were the same (Table 1). For both enzyme variants, 4-coumaric acid and isoferulic acid were the substrates accepted with the highest affinity, followed by caffeic acid, ferulic acid, and cinnamic acid (Suppl. Fig. S6).

For the co-substrate ATP Aa4CL_1 displayed a $K_{\mathrm{m}}$ value of $227.1 \pm 31.8 \mu \mathrm{M}\left(V_{\max } 18.1 \pm 4.8 \mathrm{mkat} / \mathrm{kg}\right)$ and Aa4CL_2 of $151.1 \pm 25.3 \mu \mathrm{M}\left(V_{\max } 31.2 \pm 1.0 \mathrm{mkat} / \mathrm{kg}\right)$ (Table 1 ; Suppl. Fig. S6). The $K_{\mathrm{m}}$ value for CoA was at $10.2 \pm 0.2 \mu \mathrm{M}$ $\left(V_{\max } 15.9 \pm 4.6 \mathrm{mkat} / \mathrm{kg}\right)$ for Aa4CL_1 and $14.6 \pm 3.2 \mu \mathrm{M}$ $\left(V_{\max } 35.9 \pm 2.2 \mathrm{mkat} / \mathrm{kg}\right.$ ) for Aa4CL_2 (Table 1; Suppl. Fig. S6).

\section{Expression of Aa4HBCL in E. coli and characterization of $\mathrm{Aa} 4 \mathrm{HBCL}$}

Aa4HBCL (Genbank MN922306) carried an $N$-terminally attached 6xHis tag by insertion into the expression vector pRSET C and was also expressed in E. coli SoluBL21. At first, crude protein extracts of two different transformants, expressed either in TB or LB media, were analyzed by SDSPAGE and Western blot analysis. All transformants showed a band of the expected size $(\sim 65 \mathrm{kDa})$ and protein formation was slightly higher using TB media compared to LB (Suppl. Fig. S7a). The protein was purified by metal chelate chromatography (Suppl. Fig. S7b) and tested for substrate acceptance. Photometrical analysis of assays incubated with different (hydroxy)cinnamic acids or 4-hydroxybenzoic acid (4HBA) resulted in an activation of 4HBA, isoferulic, cinnamic, 4-coumaric and caffeic acids; ferulic and sinapic acid were not converted (Suppl. Fig. S8). Crude protein extract from bacteria transformed with the empty vector served as negative control and showed no conversion of the applied substrates.

The activation of other benzoic acid derivatives was measured first with the indirect method. While a clear reduction of absorbance (based on a reduced concentration of ATP) could be detected for benzoic acid (BA) and 3-hydroxybenzoic acid (3HBA), this method was not sensitive enough to detect the conversion of the other tested substrates (Suppl. Fig. 9a). The attempt to determine kinetic values for BA, 3HBA, and 4HBA, using the indirect method, failed, because a reduction in the ATP concentration (applied at saturating concentrations for kinetic assays) was not detectable after 3-min reaction time, which was used to ensure the determination of initial reaction velocities. For this reason, only the relative conversion rates of the three substrates were compared (Suppl. Fig. S9b). The conversion rates of BA and 4HBA were the same after $30 \mathrm{~min}$, with 68\% (BA) and 67\% (4HBA) remaining ATP after $30 \mathrm{~min}$. 3HBA had the lowest conversion with $86 \%$ ATP remaining after $30 \mathrm{~min}$.

The reaction products of all benzoic acid derivatives were also analyzed by LC-MS after incubation with higher protein amounts and longer incubation times (Suppl. Fig. $\mathrm{S} 10)$. Here the formation of the expected CoA-ester in
Table 1 Kinetic data for Aa4CL_1 (a) and Aa4CL_2 (b)

\begin{tabular}{lcllc}
\hline & $K_{\mathrm{m}}(\mu \mathrm{M})$ & $V_{\max }(\mathrm{mkat} / \mathrm{kg})$ & $K_{\text {cat }}(1 / \mathrm{s})$ & $k_{\text {cat }} / K_{\mathrm{m}}(1 / \mathrm{s} \mathrm{mM})$ \\
\hline (a) Aa4CL_1 & & & \\
Cinnamic acid & $218.2 \pm 74.7$ & $16.0 \pm 2.9$ & $1.0 \pm 0.2$ & 4.6 \\
4-Coumaric acid & $12.8 \pm 4.0$ & $24.0 \pm 3.1$ & $1.5 \pm 0.2$ & 118.5 \\
Caffeic acid & $15.5 \pm 1.9$ & $16.8 \pm 2.2$ & $1.1 \pm 0.1$ & 68.3 \\
Ferulic acid & $61.4 \pm 21.9$ & $25.3 \pm 3.9$ & $1.6 \pm 0.2$ & 26.1 \\
Isoferulic acid & $9.9 \pm 1.8$ & $13.1 \pm 0.3$ & $0.8 \pm 0.02$ & 84.1 \\
ATP & $227.1 \pm 31.8$ & $18.1 \pm 4.8$ & $1.1 \pm 0.3$ & 5.0 \\
CoA & $10.2 \pm 0.2$ & $15.9 \pm 4.6$ & $1.0 \pm 0.3$ & 98.5 \\
(b) Aa4CL_2 & & & & \\
Cinnamic acid & $216.7 \pm 86.1$ & $28.5 \pm 2.9$ & $1.8 \pm 0.2$ & 8.1 \\
4-Coumaric acid & $11.8 \pm 4.4$ & $41.2 \pm 4.8$ & $2.5 \pm 0.3$ & 215.1 \\
Caffeic acid & $20.5 \pm 4.6$ & $32.3 \pm 5.8$ & $2.0 \pm 0.4$ & 97.4 \\
Ferulic acid & $65.3 \pm 21.9$ & $49.4 \pm 8.1$ & $3.1 \pm 0.5$ & 46.7 \\
Isoferulic acid & $7.5 \pm 1.8$ & $28.0 \pm 3.9$ & $1.7 \pm 0.2$ & 231.6 \\
ATP & $151.1 \pm 25.3$ & $31.2 \pm 1.0$ & $1.9 \pm 0.1$ & 12.7 \\
CoA & $14.6 \pm 3.2$ & $35.8 \pm 2.2$ & $2.2 \pm 0.1$ & 151.6 \\
\hline
\end{tabular}

$K_{\mathrm{m}}$ and $V_{\max }$ were calculated from Michaelis Menten plots by the GraphPad Prism software. Data were obtained from three technical replicates for each of the three biological replicates. All values represent mean \pm standard error 
combination with the increase in AMP concentration was determined against a negative control (heat-denatured protein) after incubation for $30 \mathrm{~min}$. The enzyme accepted BA, 3HBA, 4HBA, 2-aminobenzoic, 3-aminobenzoic, 2,3-dihydroxybenzoic, 2,4-dihydroxybenzoic, 3,4-dihydroxybenzoic (protocatechuic acid), and 2-amino-3-hydroxybenzoic acids. Moreover, the activation of 2-coumaric acid, 3-coumaric acid, 4-coumaric acid, and caffeic acid was verified by LC-MS. Salicylic acid (2HBA), 3-aminosalicylic acid (2-hydroxy-3-aminobenzoic acid), and vanillic acid (3-methoxy-4-hydroxybenzoic acid) were not converted; instead only the formation of AMP was observed. The same could be seen by applying glycolic acid as substrate (data not shown). For all produced CoA-esters, we observed the $[\mathrm{M}-\mathrm{H}]$ pseudo-molecular ion as well as the doubly charged molecular ion $[\mathrm{M} / 2]-\mathrm{H}$, as already reported by Beuerle and Pichersky (2002).

The relative activities for the accepted hydroxycinnamic acids and the three best accepted benzoic acids were compared to $4 \mathrm{HBA}$ (Fig. 2). With $90 \pm 8 \%$, BA was accepted almost as good as 4HBA. 3HBA and isoferulic acid were converted with a relative activity of $35 \pm 7 \%$ and $30 \pm 3 \%$, respectively. The least converted substrates were 4-coumaric acid $(20 \pm 0.4 \%)$, cinnamic acid $(17 \pm 0.3 \%)$, and caffeic acid $(5 \pm 0.3 \%)$.

The formation of 4HBA-CoA could be directly determined spectrophotometrically at $300 \mathrm{~nm}$ (Biegert et al. 1993). First, the $\mathrm{pH}$ as well as the temperature optimum were determined. The temperature optimum was at appr. $50{ }^{\circ} \mathrm{C}$. The $\mathrm{pH}$ optimum was at $\mathrm{pH} 7.3$ in the assay when using a $0.1 \mathrm{M}$ potassium phosphate buffer with $\mathrm{pH} 7.5$ (Suppl. Fig. S11).

The kinetic values for 4HBA, CoA, and ATP were determined with the direct photometric method. The apparent $K_{\mathrm{m}}$ value for $4 \mathrm{HBA}$ was at $664.2 \pm 1.5 \mu \mathrm{M}$ and $V_{\max }$ at $16.5 \pm 0.7 \mathrm{mkat} / \mathrm{kg}$. The $K_{\mathrm{m}}$ values for ATP and CoA were at $1.2 \pm 0.1 \mathrm{mM}$ and $247.8 \pm 19.9 \mu \mathrm{M}$, respectively, with $V_{\max }$ values of $23.4 \pm 4.7 \mathrm{mkat} / \mathrm{kg}$ and $32.5 \pm 0.8 \mathrm{mkat} / \mathrm{kg}$ (Table 2; Suppl. Fig. S12).
Table 2 Kinetic data for Aa4HBCL for its substrates 4HBA, CoA and ATP

\begin{tabular}{lclll}
\hline & Aa4HBCL & & & \\
\cline { 2 - 5 } & $K_{\mathrm{m}}(\mu \mathrm{M})$ & $V_{\max }(\mathrm{mkat} / \mathrm{kg})$ & $K_{\text {cat }}(1 / \mathrm{s})$ & $\begin{array}{l}k_{\mathrm{cat}} / K_{\mathrm{m}} \\
(1 / \mathrm{s} \mathrm{mM})\end{array}$ \\
\hline 4HBA & $664.2 \pm 1.5$ & $16.5 \pm 0.7$ & $1.1 \pm 0.1$ & 1.7 \\
ATP & $1175.3 \pm 135.2$ & $23.4 \pm 4.7$ & $1.6 \pm 0.3$ & 1.3 \\
CoA & $247.8 \pm 19.9$ & $32.5 \pm 0.8$ & $2.2 \pm 0.1$ & 8.7 \\
\hline
\end{tabular}

$K_{\mathrm{m}}$ and $V_{\max }$ were calculated from Michaelis-Menten plots by the GraphPad Prism software. Data were obtained from three technical replicates for each of the three biological replicates. All values represent mean \pm standard error

\section{Discussion}

Anthoceros agrestis can accumulate RA up to 5\% of the dry weight (Vogelsang et al. 2006). Other RA-related phenolic compounds as well as (hydroxy)cinnamic acid esters and amides have been identified as well (Takeda et al. 1990; Trennheuser 1992). Although the biosynthetic pathway for RA in the hornwort is not yet fully resolved, it is likely that activated hydroxycinnamic acids play a role. Thus, the presence of a $4 \mathrm{CL}$ was expected. Four potential A. agrestis 4CL genes were identified as scaffolds in databases from A. agrestis and a close relative, A. punctatus, the cDNAs amplified from A. agrestis and heterologously expressed in E. coli. Two of the isolated proteins (Aa4CL and Aa4HBCL) showed the formation of CoA-thioesters with phenolic acids. The third (Aa20832) was also heterologously expressed in E. coli, but until now its substrate(s) could not be identified although the reduction of ATP to AMP could be observed and thus the enzyme was considered to be active. The last potential partial sequence (Aa19917) could only be amplified with gDNA and not with cDNA in various attempts using different primer pairs, and we assume that this gene is presumably silenced.
Fig. 2 Substrate preference of Aa4HBCL in $\%$ compared to 4HBA. Data were collected either by the indirect assay for 0, 5, 15 and $30 \mathrm{~min}$ (4HBA, BA and 3HBA) or by direct photometerical measurement (4HBA, cinnamic acid, 4-coumaric acid, caffeic acid and isoferulic acid). Each bar represents the mean average of three technical replicates, the error bars represent the standard deviation

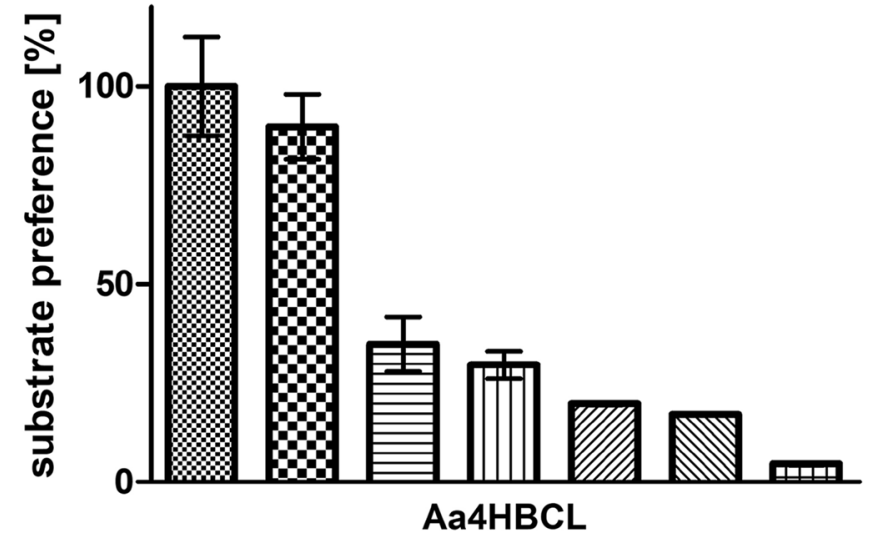

Aa4HBCL 
The full-length sequence of Aa4CL had two possible start codons and both versions of the protein have been expressed and characterized (Aa4CL_1 and Aa4CL_2). We suppose that the second start codon is used for translation based on sequence alignments with other 4CLs and a higher specific activity of the expressed protein (Aa4CL_2). The two different $N$ termini of the amino acid sequences could not be identified as a signal sequence (identification with SignalIP 4.1) and the nine nucleotides between the two possible start codons could not be attributed to a ribosome binding site (Kozak sequence). The alignment of 4CL sequences from Anthoceros and angiosperms (Fig. 1) demonstrated that the amino acids from box I and II (Uhlmann and Ebel 1993; Ehlting et al. 2001) are highly conserved throughout the plant kingdom and the 12 amino acids, which are supposed to act as the 4CL substrate specificity code, were always identical (Schneider et al. 2003). According to Schneider et al. (2003), the pattern of the last 2 of these 12 amino acids is important for the activation of sinapic acid. If both amino acids, valin and leucin, are present, sinapic acid is not converted, but if one of these amino acids is deleted, the enzyme acquires the new function towards sinapic acid (Lindermayr et al. 2002; Schneider et al. 2003). In Aa4CL, both amino acids were present and, therefore, it was not surprising that the enzyme showed no activation of sinapic acid. Nevertheless, other hydroxycinnamic acids were converted (Suppl. Figs. S2 and S3). Both expressed Aa4CL variants showed the same substrate affinities towards (hydroxy)cinnamic acids, whereas the formation of benzoyl-CoA derivatives could not be detected for Aa4CL (Suppl. Fig. S4).

Aa4CL2 (which we regard as the protein occurring in vivo; see above) accepts (hydroxy)cinnamic acids in the following order of affinities $\left(K_{\mathrm{m}}\right)$ : isoferulic $>4$-coumaric $>$ caffeic $>$ ferulic $>$ cinnamic acid (Table 1 ). The catalytic efficiencies $\left(K_{\mathrm{cat}} / K_{\mathrm{m}}\right.$; Table 1$)$ also reflect this order. However, the affinities and efficiencies for isoferulic acid and 4-coumaric acid are very close to each other. For comparison, kinetic data for 4CL with isoferulic acid as substrate are only available for Petroselinum crispum (26 $\mu \mathrm{M}$; Knobloch and Hahlbrock 1977) and Glycine max (100 $\mu \mathrm{M}$ for isoenzyme 1 and $150 \mu \mathrm{M}$ for isoenzyme 2; Knobloch and Hahlbrock 1975). This shows that Aa4CL has a considerably higher affinity towards isoferulic acid. The affinity for the second best substrate, 4-coumaric acid, with $11.8 \pm 4.4 \mu \mathrm{M}$ was in the range between $11 \mu \mathrm{M}$ for $4 \mathrm{CL}$ from Pinus taeda (Chen et al. 2014) and $16 \mu \mathrm{M}$ for Physcomitrella patens 4CL2 (Silber et al. 2008). For caffeic acid, the $K_{\mathrm{m}}$ values of different 4CLs ranged from $1 \mu \mathrm{M}$ (Nicotiana tabacum; Li and Nair 2015) to $725 \mu \mathrm{M}$ (Physcomitrella patens 4CL3; Silber et al. 2008). With 20.5 $\pm 4.6 \mu \mathrm{M}$ Aa4CL_2 from Anthoceros was within this range. This was also the case for ferulic acid $(65.3 \pm 21.9 \mu \mathrm{M})$ with $K_{\mathrm{m}}$ values ranging from $2.2 \mu \mathrm{M}$ (Oryza sativa 4CL3; Gui et al. 2011) to
$800 \mu \mathrm{M}$ (Physcomitrella patens 4CL3; Silber et al. 2008). Cinnamic acid is the substrate with the highest $K_{\mathrm{m}}$ value of $216.7 \pm 86.1 \mu \mathrm{M}$ for Aa4CL_2. This value is also in the range of published $K_{\mathrm{m}}$ values for $t$-cinnamic acid of $9.4 \mu \mathrm{M}$ (Oryza sativa 4CL1; Gui et al. 2011) to $6.63 \mathrm{mM}$ (Arabidopsis thaliana; Ehlting et al. 1999). With $151.1 \pm 25.3 \mu \mathrm{M}$, the $K_{\mathrm{m}}$ value of Aa4CL_2 for ATP was comparably high; also in wild type and mutant enzymes of Arabidopsis thaliana, values ranged between $151 \mu \mathrm{M}$ and $1.50 \mathrm{mM}$ (Stuible et al. 2000). In Forsythia suspensa and Glycine max, the $K_{\mathrm{m}}$ value for CoA ranged between $3.2 \mu \mathrm{M}$ and $7 \mu \mathrm{M}$ (Gross and Zenk 1974; Knobloch and Hahlbrock 1975). This value was slightly higher for Aa4CL_2 with 14.6 $\pm 3.2 \mu \mathrm{M}$.

Trennheuser (1992) meticulously analyzed compounds isolated from suspension-cultured cells of Anthoceros agrestis. Among the identified (hydroxy)cinnamic acid derivatives were various esters and amides of 4-coumaric, caffeic and isoferulic acids while similar adducts with ferulic acid were missing. This is reflected in the substrate acceptance of Aa4CL with a higher affinity for isoferulic acid $\left(K_{\mathrm{m}} 7.5 \mu \mathrm{M}\right)$ compared to ferulic acid $\left(K_{\mathrm{m}} 65.3 \mu \mathrm{M}\right)$. This might be a specific feature of lower plants or hornworts since isoferulic acid is not a predominant compound in seed plants where ferulic acid and its derivatives are more important, e.g., as coniferyl alcohol unit (G-unit) in lignin formation.

The presence of a benzoic acid/hydroxybenzoic acid activating enzyme in the hornwort Anthoceros agrestis was less expected. Bacterial and fungal benzoate CoA ligases function in the catabolic pathway of aromatic carboxylic acids (Thornburg et al. 2015). In Arabidopsis thaliana, benzoate CoA ligase is involved in glucosinolate biosynthesis (Kliebenstein et al. 2007) and a 3-hydroxybenzoate coenzyme A ligase from Centaurium erythraea acts in xanthone biosynthesis (Barillas and Beerhues 1997). Moreover, the production of taxanes in Taxus cuspidata is dependent on benzoyl-CoA (Walker and Croteau 2000). The role of Aa4H$\mathrm{BCL}$ in the hornwort is not yet known; however, hydroxybenzoic, protocatechuic, and vanillic acid conjugates have been identified by Trennheuser (1992) in Anthoceros agrestis. An alignment of the two published plant (hydroxy)benzoate CoA ligases from Arabidopsis thaliana (Q9SS01) and Clarkia breweri (AEO52695.1) with Aa4HBCL and Aa4CL (Fig. 1) revealed that some amino acids of the 4CL substrate specificity code might also be important for the acceptance of benzoic acid derivatives. However, all three proteins had a threonine residue in position 288 instead of an asparagine. Moreover, position 380 was changed from a glycine to an alanine residue. In position 390, valine was changed either to isoleucine or alanine.

Aa4HBCL preferably activated 4-hydroxybenzoic acid, benzoic acid and 3-hydroxybenzoic acid, but also accepted other benzoic acid derivatives at a lower rate (Suppl. Figs. S9 and S10). Salicylic acid and 3-aminosalicylic acid were 
not converted. The same substrate preference, but different affinities were found in 3-hydroxybenzoate CoA ligase from Centaurium erythraea (Barillas and Beerhues 1997). While this enzyme preferred 3HBA and converted BA and 4HBA at much lower (but similar) rates, Aa4HBCL not only favored 4HBA and BA, but also accepted 3HBA with a considerably lower conversion rate. In addition, Aa4HBCL also converted cinnamic acid derivatives, such as isoferulic, cinnamic, 2-coumaric, 3-coumaric, 4-coumaric, and caffeic acids, but did not accept ferulic acid and sinapic acid (Suppl. Figs. S8 and S10). The acceptance of substituted cinnamic acid derivatives (except sinapic acid) might be based on size exclusion. As described by Schneider et al. (2003), ferulic acid was accepted when the amino acids methionine and lysine (fourth and fifth amino acid of the 4CL substrate specificity code) were exchanged with amino acids with shorter side chains. Both Aa4HBCL and Aa4CL shared the amino acids proline and methionine at these positions. While Aa4CL accepted both ferulic and isoferulic acid, Aa4HBCL lacked affinity for ferulic acid but activated isoferulic acid. Thus, there might still be some unsolved questions concerning the 4CL substrate specificity code. Nonetheless, the specific acitvities of Aa4HBCL using cinnamic acid derivatives were about tenfold lower compared to Aa4CL. For both enzymes, the formation of AMP could be observed even for the not-converted substrates. Thus, the enzymes were able to cleave ATP to AMP and pyrophosphate even without any suitable acceptor substrate.

The $K_{\mathrm{m}}$ value for $4 \mathrm{HBA}$ was rather high at $664.2 \pm 1.5 \mu \mathrm{M}$. This value can only be compared to badA from Rhodopseudomonas palustris $(158 \mu \mathrm{M})$ (Thornburg et al. 2015) since there are no available kinetic parameters for respective plant enzymes. The benzoate-activating enzyme from $C$. breweri (Beuerle and Pichersky 2002) displayed a $K_{\mathrm{m}}$ value of $95 \mu \mathrm{M}$ for ATP. With $1.2 \pm 0.1 \mathrm{mM}$ Aa4HBCL had a much lower affinity. Also, the $K_{\mathrm{m}}$ value of $13 \mu \mathrm{M}$ from $C$. breweri for CoA is much lower than the $K_{\mathrm{m}}$ value of Aa4HBCL with $247.8 \pm 19.9 \mu \mathrm{M}$ (Table 2).

The importance of the phenylpropanoid pathway in the hornwort Anthoceros agrestis is depicted in the presence of at least two genes encoding phenylalanine ammonialyase (Pezeshki et al. in progress) and one for cinnamic acid 4-hydroxylase (CYP73A260; Wohl and Petersen 2020) as well as four putative CoA ligase genes, two of which have been described here. The strongly different substrate preferences of the two characterized CoA ligases, one preferring (hydroxy)cinnamic acids (Aa4CL, GenBank MN922305), the other (hydroxy)benzoic acids (Aa4HBCL, GenBank MN922306), are reflected in the spectrum of phenolic compounds identified in Anthoceros agrestis by Trennheuser (1992) as well as Takeda et al. (1990) and Vogelsang et al. (2006). Besides free acids, various esters and amides of 4-hydroxybenzoic, protocatechuic, vanillic, 4-coumaric, caffeic and isoferulic acids were isolated while ferulic acid esters were not found. The substrate spectra of the two CoA ligases described in this work perfectly fit to this compound spectrum. The formation of these esters and amides requires the presence of (hydroxy)benzoyl- and hydroxycinnamoyltransferases which are currently under investigation in our laboratory.

\section{Conclusion}

A 4CL and a 4HBCL from the hornwort Anthoceros agrestis were amplified and heterologously expressed in E. coli. This resulted in catalytically active 4CL and 4HBCL proteins which were characterized biochemically. While Aa4CL only accepted hydroxycinnamic acids, Aa4HBCL activated benzoic acid derivatives and some hydroxycinnamic acids.

Author contribution statement JW and MP conceived and designed the research. JW conducted the experiments, and JW and MP analyzed the data and wrote the manuscript. Both authors read and approved the manuscript.

Acknowledgements Open Access funding provided by Projekt DEAL. We would like to thank Dr. Peter Szövenyi (University of Zurich, Switzerland) for searching for us the 4CL-candidate scaffold in his Anthoceros agrestis transcriptome database. Furthermore, we would like to thank Rixa Kraut (Universität Marburg) for performing LC-MS analyzes and Elke Bauerbach and Olga Haag for technical assistance. The Bruker micrOTOF QIII mass spectrometer was financially supported in part by a grant from the Deutsche Forschungsgemeinschaft (INST 160/620-1) to Prof. Dr. Shu-Ming Li, Philipps-Universität Marburg.

\section{Compliance with ethical standards}

Conflict of interest The authors declare that they have no conflict of interest.

Open Access This article is licensed under a Creative Commons Attribution 4.0 International License, which permits use, sharing, adaptation, distribution and reproduction in any medium or format, as long as you give appropriate credit to the original author(s) and the source, provide a link to the Creative Commons licence, and indicate if changes were made. The images or other third party material in this article are included in the article's Creative Commons licence, unless indicated otherwise in a credit line to the material. If material is not included in the article's Creative Commons licence and your intended use is not permitted by statutory regulation or exceeds the permitted use, you will need to obtain permission directly from the copyright holder. To view a copy of this licence, visit http://creativecommons.org/licenses/by/4.0/. 


\section{References}

An JH, Lee GY, Jung JW, Lee W, Kim YS (1999) Identification of residues essential for a two-step reaction by malonyl-CoA synthetase from Rhizobium trifolii. Biochem J 344:159-166. https:// doi.org/10.1042/bj3440159

Barillas W, Beerhues L (1997) 3-Hydroxybenzoate:coenzyme A ligase and 4-coumarate:coenzyme A ligase from cultured cells of Centaurium erythraea. Planta 202:112-116. https://doi.org/10.1007/ s004250050109

Beuerle T, Pichersky E (2002) Purification and characterization of benzoate: coenzyme A ligase from Clarkia breweri. Arch Biochem Biophys 400:258-264. https://doi.org/10.1016/S0003 -9861(02)00026-7

Biegert T, Altenschmidt U, Eckerskorn C, Fuchs G (1993) Enzymes of anaerobic metabolism of phenolic compounds: 4-Hydroxybenzoate-CoA ligase from a denitrifying Pseudomonas species. Eur J Biochem 213:555-561. https://doi. org/10.1111/j.1432-1033.1993.tb17794.x

Block A, Widhalm JR, Fatihi A, Cahoon RE, Wamboldt Y, Elowsky C, Mackenzie SA, Cahoon EB, Chapple C, Dudareva N, Basset GJ (2014) The origin and biosynthesis of the benzenoid moiety of ubiquinone (coenzyme Q) in Arabidopsis. Plant Cell 26:1938-1948. https://doi.org/10.1105/tpc.114.125807

Bradford MM (1976) A rapid and sensitive method for the quantitation of microgram quantities of protein utilizing the principle of protein-dye binding. Anal Biochem 72:248-254. https://doi. org/10.1016/0003-2697(76)90527-3

Chang KH, Xiang H, Dunaway-Mariano D (1997) Acyl-adenylate motif of the acyl-adenylate/thioester-forming enzyme superfamily: a site-directed mutagenesis study with the Pseudomonas sp. strain CBS3 4-chlorobenzoate: coenzyme A ligase. Biochemistry 36:15650-15659. https://doi.org/10.1021/bi971262p

Chen HY, Babst BA, Nyamdari B, Hu H, Sykes R, Davis MF, Harding SA, Tsai CJ (2014) Ectopic expression of a loblolly pine class II 4-coumarate: CoA ligase alters soluble phenylpropanoid metabolism but not lignin biosynthesis in Populus. Plant Cell Physiol 55:1669-1678. https://doi.org/10.1093/pcp/pcu098

Chomczynski P, Sacchi N (1987) Single-step method of RNA isolation by acid guanidinium thiocyanate-phenol-chloroform extraction. Anal Biochem 162:156-159. https://doi.org/10.1016/00032697(87)90021-2

Conti E, Franks NP, Brick P (1996) Crystal structure of firefly luciferase throws light on a superfamily of adenylate-forming enzymes. Structure 4:287-298. https://doi.org/10.1016/S0969 -2126(96)00033-0

Conti E, Stachelhaus T, Marahiel MA, Brick P (1997) Structural basis for the activation of phenylalanine in the non-ribosomal biosynthesis of gramicidin S. EMBO J 16:4174-4183. https:// doi.org/10.1093/emboj/16.14.4174

Dudareva N, Pichersky E, Gershenzon J (2004) Biochemistry of plant volatiles. Plant Physiol 135:1893-1902. https://doi.org/10.1104/ pp.104.049981

Dudareva N, Negre F, Nagegowda DA, Orlova I (2006) Plant volatiles: recent advances and future perspectives. Crit Rev Plant Sci 25:417-440. https://doi.org/10.1080/07352680600899973

Dudareva N, Klempien A, Muhlemann JK, Kaplan I (2013) Biosynthesis, function and metabolic engineering of plant volatile organic compounds. New Phytol 198:16-32. https://doi. org/10.1111/nph.12145

Egland PG, Gibson J, Harwood CS (1995) Benzoate-coenzyme A ligase, encoded by badA, is one of three ligases able to catalyze benzoyl-coenzyme A formation during anaerobic growth of Rhodopseudomonas palustris on benzoate. J Bacteriol 177:6545-6551. https://doi.org/10.1128/ jb.177.22.6545-6551.1995

Ehlting J, Büttner D, Wang Q, Douglas CJ, Somssich IE, Kombrink E (1999) Three 4-coumarate: coenzyme A ligases in Arabidopsis thaliana represent two evolutionarily divergent classes in angiosperms. Plant J 19:9-20. https://doi.org/10.1046/j.1365313X.1999.00491.x

Ehlting J, Shin JJ, Douglas CJ (2001) Identification of 4-coumarate: coenzyme A ligase (4CL) substrate recognition domains. Plant J 27:455-465. https://doi.org/10.1046/j.1365-313X.2001.01122.x

Gaisser S, Heide L (1996) Inhibition and regulation of shikonin biosynthesis in suspension cultures of Lithospermum. Phytochemistry 41:1065-1072. https://doi.org/10.1016/00319422(95)00633-8

Gibson J, Dispensa M, Fogg GC, Evans DT, Harwood CS (1994) 4-Hydroxybenzoate-coenzyme A ligase from Rhodopseudomonas palustris: purification, gene sequence, and role in anaerobic degradation. J Bacteriol 176:634-641. https://doi.org/10.1128/ jb.176.3.634-641.1994

Goff SA, Klee HJ (2006) Plant volatile compounds: sensory cues for health and nutritional value? Science 311:815-819. https://doi. org/10.1126/science.1112614

Gross GG, Zenk MH (1974) Isolation and properties of hydroxycinnamate: CoA ligase from lignifying tissue of Forsthia. Eur J Biochem 42:453-459. https://doi.org/10.1111/j.1432-1033.1974. tb03359.x

Gui J, Shen J, Li L (2011) Functional characterization of evolutionarily divergent 4-coumarate: coenzyme A ligases in rice. Plant Physiol 157:574-586. https://doi.org/10.1104/pp.111.17830

Kim HU, Oostende CV, Basset GJ, Browse J (2008) The AAE14 gene encodes the Arabidopsis o-succinylbenzoyl-CoA ligase that is essential for phylloquinone synthesis and photosystem-I function. Plant J 54:272-283. https://doi.org/10.1111/j.1365313X.2008.03416.X

Klempien A, Kaminaga Y, Qualley A, Nagegowda DA, Widhalm JR, Orlova I, Shasany AK, Taguchi G, Kish KM, Cooper BR, D'Auria JC, Rhodes D, Pichersky E, Dudareva N (2012) Contribution of CoA ligases to benzenoid biosynthesis in petunia flowers. Plant Cell 24:2015-2030. https://doi.org/10.1105/ tpc.112.097519

Kliebenstein DJ, D’Auria JC, Behere AS, Kim JH, Gunderson KL, Breen JN, Lee G, Gershenzon J, Last RL, Jander G (2007) Characterization of seed-specific benzoyloxyglucosinolate mutations in Arabidopsis thaliana. Plant J 51:1062-1076. https://doi. org/10.1111/j.1365-313X.2007.03205.x

Knobloch KH, Hahlbrock K (1975) Isoenzymes of $p$-coumarate: CoA ligase from cell suspension cultures of Glycine max. Eur J Biochem 52:311-320. https://doi.org/10.1111/j.1432-1033.1975. tb03999.x

Knobloch KH, Hahlbrock K (1977) 4-Coumarate: CoA ligase from cell suspension cultures of Petroselinum hortense Hoffm: partial purification, substrate specificity, and further properties. Arch Biochem Biophys 184:237-248. https://doi.org/10.1016/00039861(77)90347-2

Köllner TG, Lenk C, Zhao N, Seidl-Adams I, Gershenzon J, Chen F, Degenhardt J (2010) Herbivore-induced SABATH methyltransferases of maize that methylate anthranilic acid using $S$-adenosyl-L-methionine. Plant Physiol 153:1795-1807. https://doi. org/10.1104/pp.110.158360

Labeeuw L, Martone PT, Boucher Y, Case RJ (2015) Ancient origin of the biosynthesis of lignin precursors. Biol Direct 10:23. https ://doi.org/10.1186/s13062-015-0052-y

Laemmli UK (1970) Cleavage of structural proteins during assembly of the head of bacteriophage T4. Nature 227:680-685. https://doi. org/10.1038/227680a0 
Leon J, Shulaev V, Yalpani N, Lawton MA, Raskin I (1995) Benzoic acid 2-hydroxylase, a soluble oxygenase from tobacco, catalyzes salicylic acid biosynthesis. Proc Natl Acad Sci USA 92:1041310417. https://doi.org/10.1073/pnas.92.22.10413

Lessard JC (2013) Growth media for E. coli. Methods Enzymol 533:181-189. https://doi.org/10.1016/B978-0-12-420067-8.00011 $-8$

Li Z, Nair SK (2015) Structural basis for specificity and flexibility in a plant 4-coumarate: CoA ligase. Structure 23:2032-2042. https ://doi.org/10.1016/j.str.2015.08.012

Li Y, Kim JI, Pysh L, Chapple C (2015) Four isoforms of Arabidopsis 4-coumarate: CoA ligase have overlapping yet distinct roles in phenylpropanoid metabolism. Plant Physiol 169:2409-2421. https ://doi.org/10.1104/pp.15.00838

Lindermayr C, Möllers B, Fliegmann J, Uhlmann A, Lottspeich F, Meimberg H, Ebel J (2002) Divergent members of a soybean (Glycine $\max$ L.) 4-coumarate: coenzyme A ligase gene family: primary structures, catalytic properties, and differential expression. Eur J Biochem 269:1304-1315. https://doi.org/10.104 6/j.1432-1033.2002.02775.x

Mahmood T, Yang PC (2012) Western blot: technique, theory, and trouble shooting. N Am J Med Sci 4:429. www.najms.org/text. asp?2012/4/9/429/100998

Mutui TM, Mibus H, Serek M (2012) Effect of meta-topolin on leaf senescence and rooting in Pelargonium $\times$ hortorum cuttings. Postharvest Biol Technol 63:107-110. https://doi.org/10.1016/j.posth arvbio.2011.09.010

Ogawa D, Nakajima N, Sano T, Tamaoki M, Aono M, Kubo A, Kanna M, Ioki M, Kamada H, Saji H (2005) Salicylic acid accumulation under $\mathrm{O}_{3}$ exposure is regulated by ethylene in tobacco plants. Plant Cell Physiol 46:1062-1072. https://doi.org/10.1093/pcp/pci118

Ogawa D, Nakajima N, Seo S, Mitsuhara I, Kamada H, Ohashi Y (2006) The phenylalanine pathway is the main route of salicylic acid biosynthesis in tobacco mosaic virus-infected tobacco leaves. Plant Biotechnol 23:395-398. https://doi.org/10.5511/plantbiote chnology.23.395

Pan Q, Zhan J, Liu H, Zhang J, Chen J, Wen P, Huang W (2006) Salicylic acid synthesized by benzoic acid 2-hydroxylase participates in the development of thermotolerance in pea plants. Plant Sci 171:226-233. https://doi.org/10.1016/j.plantsci.2006.03.012

Petersen M (2003) Cinnamic acid 4-hydroxylase from cell cultures of the hornwort Anthoceros agrestis. Planta 217:96-101. https://doi. org/10.1007/s00425-002-0960-9

Petersen M, Simmonds MSJ (2003) Molecules of interest: rosmarinic acid. Phytochemistry 62:121-125. https://doi.org/10.1016/S0031 -9422(02)00513-7

Petersen M, Häusler E, Karwatzki B, Meinhard J (1993) Proposed biosynthetic pathway for rosmarinic acid in cell cultures of Coleus blumei Benth. Planta 189:10-14. https://doi.org/10.1007/BF002 01337

Petersen M, Abdullah Y, Benner J, Eberle D, Gehlen K, Hücherig S, Janiak V, Kim KH, Sander M, Weitzel C, Wolters S (2009) Evolution of rosmarinic acid biosynthesis. Phytochemistry 70:16631679. https://doi.org/10.1016/j.phytochem.2009.05.010

Qualley AV, Dudareva N (2008) Aromatic volatiles and their involvement in plant defense. In: Schaller A (ed) Induced plant resistance to herbivory. Springer, Dordrecht, pp 409-432. https://doi. org/10.1007/978-1-4020-8182-8_20

Renault H, Werck-Reichhart D, Weng JK (2019) Harnessing lignin evolution for biotechnological applications. Curr Opin Biotechnol 56:105-111. https://doi.org/10.1016/j.copbio.2018.10.011

Rensing SA (2018) Great moments in evolution: the conquest of land by plants. Curr Opin Plant Biol 42:49-54. https://doi. org/10.1016/j.pbi.2018.02.006
Sambrook J, Russell D (2001) Molecular cloning: a laboratory manual, 3rd edn. Cold Spring Harbor Laboratory Press, New York

Sawada H, Shim IS, Usui K (2006) Induction of benzoic acid 2-hydroxylase and salicylic acid biosynthesis - modulation by salt stress in rice seedlings. Plant Sci 171:263-270. https://doi.org/10.1016/j. plantsci.2006.03.020

Schmidt W, Beerhues L (1997) Alternative pathways of xanthone biosynthesis in cell cultures of Hypericum androsaemum L. FEBS Lett 420:143-146. https://doi.org/10.1016/S0014-5793(97)01507 $-\mathrm{X}$

Schneider K, Hövel K, Witzel K, Hamberger B, Schomburg D, Kombrink E, Stuible HP (2003) The substrate specificity-determining amino acid code of 4-coumarate: CoA ligase. Proc Natl Acad Sci USA 100:8601-8606. https://doi.org/10.1073/pnas.1430550100

Schwab W, Davidovich-Rikanati R, Lewinsohn E (2008) Biosynthesis of plant-derived flavor compounds. Plant J 54:712-732. https:// doi.org/10.1111/j.1365-313X.2008.03446.x

Shockey JM, Fulda MS (2003) Arabidopsis contains a large superfamily of acyl-activating enzymes. Phylogenetic and biochemical analysis reveals a new class of acyl-coenzyme A synthetases. Plant Physiol 132:1065-1076. https://doi.org/10.1104/pp.103.020552

Silber MV, Meimberg H, Ebel J (2008) Identification of a 4-coumarate: CoA ligase gene family in the moss, Physcomitrella patens. Phytochemistry 69:2449-2456. https://doi.org/10.1016/j.phyto chem.2008.06.014

Staswick PE, Tiryaki I (2004) The oxylipin signal jasmonic acid is activated by an enzyme that conjugates it to isoleucine in Arabidopsis. Plant Cell 16:2117-2127. https://doi.org/10.1105/tpc.104.02354

Stöckigt J, Zenk MH (1975) Chemical syntheses and properties of hydroxycinnamoyl-coenzyme A derivatives. Z Naturforsch C 30:352-358. https://doi.org/10.1515/znc-1975-5-609

Strnad M (1997) The aromatic cytokinins. Physiol Plant 101:674-688. https://doi.org/10.1111/j.1399-3054.1997.tb01052.x

Stuible HP, Kombrink E (2001) Identification of the substrate specificity-conferring amino acid residues of 4-coumarate: coenzyme A ligase allows the rational design of mutant enzymes with new catalytic properties. J Biol Chem 276:26893-26897. https://doi. org/10.1074/jbc.M100355200

Stuible HP, Büttner D, Ehlting J, Hahlbrock K, Kombrink E (2000) Mutational analysis of 4-coumarate: CoA ligase identifies functionally important amino acids and verifies its close relationship to other adenylate-forming enzymes. FEBS Lett 467:117-122. https://doi.org/10.1016/S0014-5793(00)01133-9

Szövényi P, Frangedakis E, Ricca M, Quandt D, Wicke S, Langdale JA (2015) Establishment of Anthoceros agrestis as a model species for studying the biology of hornworts. BMC Plant Biol 15:98. https://doi.org/10.1186/s12870-015-0481-x

Takeda R, Hasegawa J, Shinozaki M (1990) The first isolation of lignans, megacerotonic acid and anthocerotonic acid, from nonvascular plants, Anthocerotae (hornworts). Tetrahedron Lett 31:4159-4162. https://doi.org/10.1016/S0040-4039(00)97569-5

Tarkowská D, Doležal K, Tarkowski P, Åstot C, Holub J, Fuksová K, Schmülling T, Sandberg G, Strnad M (2003) Identification of new aromatic cytokinins in Arabidopsis thaliana and Populus $\times$ canadensis leaves by LC-(+) ESI-MS and capillary liquid chromatography/frit-fast atom bombardment mass spectrometry. Physiol Plant 117:579-590. https://doi.org/10.103 4/j.1399-3054.2003.00071.x

Thornburg CK, Wortas-Strom S, Nosrati M, Geiger JH, Walker KD (2015) Kinetically and crystallographically guided mutations of a benzoate CoA ligase (BadA) elucidate mechanism and expand substrate permissivity. Biochemistry 54:6230-6242. https://doi. org/10.1021/acs.biochem.5b00899 
Tohge T, Obata T, Fernie AR (2014) Biosynthesis of the essential respiratory cofactor ubiquinone from phenylalanine in plants. Mol Plant 7:1403-1405. https://doi.org/10.1093/mp/ssu081

Towbin H, Staehelin T, Gordon J (1979) Electrophoretic transfer of proteins from polyacrylamide gels to nitrocellulose sheets-procedure and some applications. Proc Natl Acad Sci USA 76:43504354. https://doi.org/10.1073/pnas.76.9.4350

Trennheuser F (1992) Phytochemische Untersuchung und in vitro Kultur ausgewählter Vertreter der Anthocerotopsida. $\mathrm{PhD}$ thesis, University of Saarbrücken

Trennheuser F, Burkhard G, Becker H (1994) Anthocerodiazonin, an alkaloid from Anthoceros agrestis. Phytochemistry 37:899-903. https://doi.org/10.1016/S0040-4039(00)97569-5

Uhlmann A, Ebel J (1993) Molecular cloning and expression of 4-coumarate: coenzyme A ligase, an enzyme involved in the resistance response of soybean (Glycine $\max \mathrm{L}$.) against pathogen attack. Plant Physiol 102:1147-1156. https://doi.org/10.1104/ pp.102.4.1147

Vlot AC, Dempsey DA, Klessig DF (2009) Salicylic acid, a multifaceted hormone to combat disease. Annu Rev Phytopathol 47:177206. https://doi.org/10.1146/annurev.phyto.050908.135202

Vogelsang K, Schneider B, Petersen M (2006) Production of rosmarinic acid and a new rosmarinic acid $3^{\prime}-O$ - $\beta$-D-glucoside in suspension cultures of the hornwort Anthoceros agrestis Paton. Planta 223:369-373. https://doi.org/10.1007/s00425-005-0089-8

Walker K, Croteau R (2000) Taxol biosynthesis: molecular cloning of a benzoyl-CoA: taxane $2 \alpha-O$-benzoyltransferase cDNA from Taxus and functional expression in Escherichia coli. Proc Natl Acad Sci USA 97:13591-13596. https://doi.org/10.1073/pnas.250491997

Wang J, Luca VD (2005) The biosynthesis and regulation of biosynthesis of Concord grape fruit esters, including 'foxy' methylanthranilate. Plant J 44:606-619. https://doi.org/10.1111/j.1365313X.2005.02552.x

Watkins PA (1997) Fatty acid activation. Prog Lipid Res 36:55-83. https://doi.org/10.1016/S0163-7827(97)00004-0
Werbrouck SP, Strnad M, Van Onckelen HA, Debergh PC (1996) Meta-topolin, an alternative to benzyladenine in tissue culture? Physiol Plant 98:291-297. https://doi.org/10.103 4/j.1399-3054.1996.980210.x

Wickett NJ, Mirarab S, Nguyen N, Warnow T, Carpenter E, Matasci N, Ayyampalayam S, Barker MS, Burleigh JG, Gitzendanner MA, Ruhfel BR, Wafula E, Der JP, Graham SW, Mathews S, Melkonian M, Soltis DE, Soltis PS, Miles NW, Rothfels CJ, Pokorny L, Shaw AJ, DeGironimo L, Stevenson DW, Surek B, Villarreal JC, Roure B, Philippe H, dePamphilis CW, Chen T, Deyholos MK, Baucom RS, Kutchan TM, Augustin MM, Wang J, Zhang Y, Tian Z, Yan Z, Wu X, Sun X, Wong GKS, Leebens-Mack J (2014) Phylotranscriptomic analysis of the origin and early diversification of land plants. Proc Natl Acad Sci USA 111:E4859-E4868. https://doi. org/10.1073/pnas.1323926111

Widhalm JR, Dudareva N (2015) A familiar ring to it: biosynthesis of plant benzoic acids. Mol Plant 8:83-97. https://doi.org/10.1016/j. molp.2014.12.001

Wildermuth MC (2006) Variations on a theme: synthesis and modification of plant benzoic acids. Curr Opin Plant Biol 9:288-296. https ://doi.org/10.1016/j.pbi.2006.03.006

Wohl J, Petersen M (2020) Functional expression and characterization of cinnamic acid 4-hydroxylase from the hornwort Anthoceros agrestis in Physcomitrella patens. Plant Cell Rep 39:597-607. https://doi.org/10.1007/s00299-020-02517

Zenk MH (1979) Recent work on cinnamoyl CoA derivatives. In: Swain T, Harborne JB, Van Sumere CF (eds) Biochemistry of plant phenolics. Springer, Boston, pp 139-176. https://doi. org/10.1007/978-1-4684-3372-2_5

Publisher's Note Springer Nature remains neutral with regard to jurisdictional claims in published maps and institutional affiliations. 